\title{
A Comparative Study of Metacognitive Awareness of Reading Strategies among Monolingual and Bilingual Iranian EFL Learners
}

\author{
Mohammad H. Keshavarz (Corresponding Author) \\ ELT Department \\ Near East University \\ North Cyprus \\ E-mail: keshavarz22@gmail.com \\ Masoume Ghamoushi \\ English Department \\ Khatam University, Tehran, Iran
}

\author{
Doi:10.7575/aiac.alls.v.5n.4p.25 \\ URL: http://dx.doi.org/10.7575/aiac.alls.v.5n.4p.25
}

Received: $12 / 04 / 2014$

Accepted: 09/06/2014

\begin{abstract}
Some researchers argue that linguistic knowledge of one's native language facilitates the acquisition of additional languages (see, for example, Cenoz \& Valencia, 1994; Grenfell \& Harris, 2006; Hakuta, 1990; Keshavarz \& Astaneh, 2004). To contribute to this line of research, the present study investigated the probability of significant differences among monolingual and bilingual EFL learners in their awareness and perceived use of metacognitive reading strategies and in the subscales of these strategies (i.e., global, supportive, and problem-solving strategies). To achieve this goal, 100 Persian monolingual and 100 Azeri Turkish-Persian bilingual second-year university students, majoring in English Literature, ELT, and Translation with the age range of 20-28 participated in the study. Both groups completed the Metacognitive Reading Strategies Inventory (MARSI) questionnaire. Participants' reading strategy use was determined by asking them to rate their self-perceived reading ability in reading English course books on a 5-point Likert scale. The results of data analyses revealed significant differences between monolingual and bilingual learners in the use of overall and global metacognitive reading strategies with bilingual learners having greater awareness of these two strategies. However, no significant difference was found between monolingual and bilingual participants in the use of problemsolving and supportive metacognitive strategies. This may be due to variables such as language proficiency level and attitudes towards reading that were not taken into consideration in the present study. Based on the results, it can be concluded that bilingualism enhances learners' overall awareness and use of metacognitive reading strategies. In conclusion, the findings indicated that monolingual learners, compared to bilinguals, were less aware of global and overall metacognitive reading strategies. Therefore, EFL teachers should try to increase monolingual students' awareness of such strategies and help them become, what Pressley \& Afflerbach (1995) call, constructively responsive readers.
\end{abstract}

Keywords: Bilingualism, metacognitive strategies, metagognitive awareness of reading strategies, EFL learners

\section{Introduction}

A distinction has been made between cognitive and metacognitive reading strategies by scholars in the field, most notably Oxford (1990) and Chamot \& O’Malley (1996). Cognitive reading strategies have been defined as strategies that enable learners to accomplish the reading task, such as summarizing, inferencing, note-taking, and using contextual clues. Metacognitive strategies, on the other hand, are those actions "which go beyond purely cognitive devices, and which provide a way for learners to coordinate their own learning process" (Oxford, 1990, p. 136). These strategies, as Lawrence (2007, p. 56) says, "involve self-reflection and thinking about reading and learning".

The significant role of metacognitive awareness in reading comprehension has been widely acknowledged (Alexander \& Jetton, 2000; Guthrie \& Wigfield, 1999; Pressley, 2000; Şenay Şen, 2009; Sheory \& Mokhtari, 2001; and Xianming, 2007). There is general consensus among researchers that metacognition, i.e., strategic awareness and monitoring of the comprehension process on the part of the language learner, is a significant aspect of successful reading (Alexander \& Jetton, 2000; Pressley, 2000; Pressley \& Afflerbach, 1995; and Sheory \& Mokhtari, 2001).

Research findings indicate that metacognitive strategies differentiate successful learners from unsuccessful ones. In other words, the more students know about how they learn, the better learners they will be (Anderson, 2002; Cohen, 1998; Santana, 2003). Grabe \& Stoller (2002) consider metacognitive knowledge as the main criterion for testing a reader's explicit and conscious use of reading strategies for planning, regulating, and monitoring reading 
comprehension. Also research studies conducted in both L1 and L2 contexts point to the fact that language learners' metacognitive awareness can potentially lead to effective reading strategies (Carrell, Pharis, \& Liberto, 1989).

Another factor that may have an impact on learners' strategy use and awareness is whether they are monolingual or bilingual. Some researchers argue that knowing more than one language facilitates the acquisition of additional languages (Cenoz \& Valencia, 1994; Grenfell \& Harris, 2006; Hakuta, 1990; Keshavarz \& Astaneh, 2004). For example, Hakuta (1990) asserted that "bilingualism can lead to superior performance on a variety of intellectual skills" (p.7). Grenfell \& Harris (2006) also state that bilinguals have greater linguistic knowledge of the way different language systems work. Cenoz \& Valencia (1994, p .205) conclude that "positive transfer of Basque and Spanish skills to the third language (i.e., English) is more likely to occur in the case of bilingual subjects :the knowledge of the two languages provides them with more resources." With regard to the acquisition of specific components of the target language, such as vocabulary and grammar, some studies (Keshavarz \& Astaneh, 2004; Klein, 1995; Zobl, 1993) suggest that bilingual learners outperform monolingual learners of second or foreign languages.

A large number of studies (e.g., Block, 1992; Hong-Nam \& Leavell, 2007; Moreno \& DiVesta, 1991; Lawrence, 2007; Padron, Knight, \& Waxman, 1986; Padron \& Waxman, 2001; and Tuncer, 2009) have also been conducted on the differences in strategy use among bilingual and monolingual EFL learners. Block (1992), for instance, investigated the reading strategies of 14 Chinese-Spanish bilingual learners of English and 11 monolingual English-speaking university students. The results of this study indicated that proficient bilingual learners outperformed their less proficient peers in the use of cognitive and metacognitive reading strategies, but the monolingual readers used these strategies more often than both bilingual groups .Hardin (2001) also found that Spanish-English bilingual participants in his study transferred strategic behaviors from Spanish to English and vice-versa irrespective of their proficiency level. However, proficiency level of the participants had an impact on their use of learning strategies. That is, the high-proficiency group considered reading as a meaning-making activity and made use of reading strategies such as rereading and paraphrasing in both languages, while the lowest proficiency group concentrated more on mechanical aspects of reading.

Maghsudi \& Talebi (2009) investigated the effect of bilinguality on the awareness and use of cognitive, metacognitive, and total cognitive/metacognitive strategies with regard to the participants' proficiency levels. The participants comprised 157 male and female first year pre-university students from private and state colleges in Mysore, India, where English is the medium of instruction. The findings of this study pointed to the fact that bilingual learners gained significantly higher scores than monolingual students in the awareness and use of the aforementioned strategies. The researchers also found that highly proficient students scored significantly higher than low-proficient learners, however the interaction effect between linguality and proficiency level was not significant in the awareness and perceived use of these strategies.

Tuncer (2009) compared the use of language learning strategies by 246 male and female monolingual and bilingual EFL learners at Mersin University, taking into consideration the role of gender and language proficiency of the learners. The results of this study show that of these three variables only bilinguality had a significant effect on the use of language learning strategies.

The findings of the studies outlined above indicate that further research needs to be done on the relationship between learners' linguality and metacognitive awareness in different EFL contexts. Therefore, to make a contribution to the field, the present study seeks to answer the following research questions:

1. Are there any significant differences between monolingual and bilingual EFL

learners' overall awareness of metacognitive reading strategies (henceforth MRSs)?

2. Are there any significant differences between monolingual and bilingual EFL learners' awareness of global MRSs?

3. Are there any significant differences between monolingual and bilingual EFL learners' awareness of problem-solving MRSs?

4. Are there any significant differences between monolingual and bilingual EFL learners' awareness of supportive MRSs?

\section{Method}

\subsection{Participants}

100 Persian monolingual and 100 Azeri-Persian bilingual second-year university students with the age range of 20-28 participated in this study. They were majoring in English literature, ELT, or translation. The selection of the participants was based on their accessibility (i.e., convenience sampling). The Persian monolingual sample was selected from Karaj Islamic Azad University and the bilingual participants were chosen from Tabriz Islamic Azad University. The home language of bilingual participants is Azeri Turkish, and Persian is the official language of the country and the medium of instruction nationwide at all educational levels. However, for students majoring in English literature, translation and ELT at universities in Iran, English is the medium of instruction.

\subsection{Instrumentation}

To collect the required data, Metacognitive Awareness of Reading Strategies Inventory (MARSI), developed by Mokhtari \& Reichard (2002) in English (see the Appendix), was used. The subscales of MARSI include global, problem-solving, and supportive strategies. Global strategies have been defined by the authors as "a set of generalized, intentional reading strategies oriented toward a global analysis of text that aim at setting the stage for the reading act 
(e.g., setting purpose for reading, making prediction)" (Mokhtari \& Reichard, 2002, p.252). They have also defined problem-solving strategies as "localized, focused strategies which appear to be oriented toward solving problems when a text becomes difficult to read" (p.252). Similarly, Mokhtari \& Reichard (2002) have defined supportive strategies as "those that involve use of outside reference materials, taking notes, and other practical strategies that might be described as functional or support strategies" (p.253).

Keshavarz \& Assar (2009) translated MARSI into Persian. They measured the reliability index of the translated MARSI by applying the Cronbach alpha formula, which was found to be 0.79 . To further ensure the reliability of the translated version of MARSI for the purposes of the present study, a pilot study was conducted in which 30 students participated. The reliability of the pilot study was 0.77 , using Cronbach alpha formula.

\subsection{Design}

Due to the nature of the study, correlational design was chosen. In the present study, learners' linguality was considered as the independent variable and their awareness of MRSs as the dependent variable.

\subsection{Procedure}

\subsubsection{Administration of the instrument}

Before administering the MARSI questionnaire, the participants were provided with a brief overview of the purpose of the study as well as the description of the instrument. The participants were instructed to read each of the 30 statements in the MARSI questionnaire and mark the number which best described their perceived use of the strategies, described in the statements using a Likert scale ranging from 1 to 5 . The participants were also assured that their responses will be kept confidential and their performance will not have any effect on their final exam scores.

From the population of monolinguals and bilinguals some students were eliminated because they had not properly completed their questionnaires.

\subsubsection{The Scoring Procedure}

For scoring the MARSI questionnaire, the procedure proposed by Mokhtari \& Reichard (2002) was utilized. First, the items were unscrambled according to the inventory scoring rubric. Then, a score was assigned to each answer, which ranged from 1 to 5 : never or almost never $=1$, only occasionally $=2$, sometimes $=3$, usually $=4$, and always or almost always $=5$. Then, the scores for all items were added up and an ultimate score was calculated. The range of scores for this scale (i.e., overall use of metacognitive reading strategies) was between 30 to150.

Next, the unscrambled items were divided into three categories according to the scoring rubric. These three subscales showed three different kinds of Metacognitive Reading Strategies. The first subscale (Global Reading Strategies) consisted of 13 items, the second one (Problem-Solving Strategies) 8 items, and the third subscale (Supportive Strategies) comprised 9 items.

After adding up the scores for each subscale their mean was calculated and a T-test was run, using SPSS, Version 16.0.

\section{Results}

To answer the first research question, whether there is any significant difference between monolingual and bilingual EFL learners' overall awareness of MRSs, an Independent Samples T-test was run. Table 1 displays the results.

Table 1. Independent sample T-test for overall awareness of MRSs

\begin{tabular}{llcccc}
\hline & Linguality & $\mathrm{N}$ & Mean & Std. Deviation & $\begin{array}{c}\text { Std. Error } \\
\text { Mean }\end{array}$ \\
\hline $\begin{array}{l}\text { Overall } \\
\text { MRSs }\end{array}$ & Monolingual & 100 & 3.5412 & .30723 & .03072 \\
& Bilingual & 100 & 3.6783 & .35258 & .03526 \\
\hline
\end{tabular}

Independent Samples Test

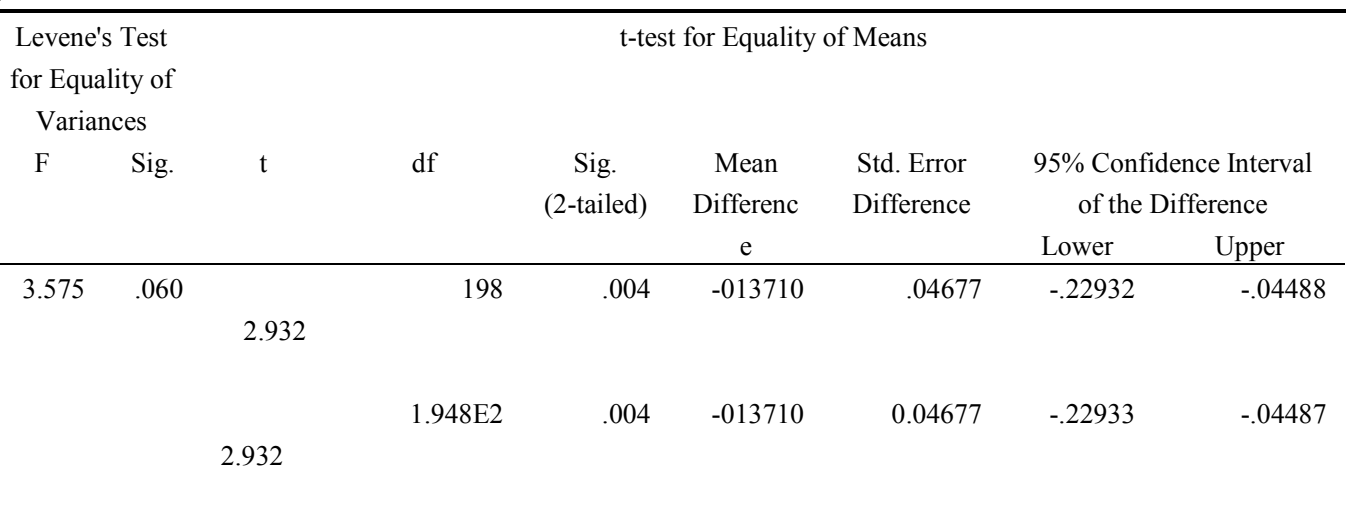


As the results show $(\mathrm{t}=2.93, \mathrm{df}=198, \mathrm{P}<0.05)$, the value of $\mathrm{P}=0.004$ is lower than 0.05 indicating that there is a significant difference between monolingual and bilingual EFL learners' overall use of MRSs. In other words, bilingual learners made more frequent use of these strategies, compared to monolingual participants.

In order to probe the second research question, an Independent Samples T-test was applied to compare monolingual and bilingual mean scores on the perceived use of Global MRSs. The results are presented in Table 2.

Table 2. Independent sample T-test for Global MRSs

\begin{tabular}{llllrr}
\hline & Linguality & $\mathrm{N}$ & Mean & Std. Deviation & Std. Error Mean \\
\hline \multirow{2}{*}{ Global } & Monolingual & 100 & 3.4460 & .41117 & .04112 \\
MRSs & & 100 & 3.6456 & .42740 & .04274 \\
& Bilingual & & & & \\
\hline
\end{tabular}

\begin{tabular}{|c|c|c|c|c|c|c|c|c|c|c|}
\hline \multicolumn{11}{|c|}{ Independent Samples Test } \\
\hline & & \multicolumn{2}{|c|}{$\begin{array}{l}\text { Levene's Test } \\
\text { for Equality } \\
\text { of Variances }\end{array}$} & \multicolumn{7}{|c|}{ t-test for Equality of Means } \\
\hline & & $\mathrm{F}$ & Sig. & $\mathrm{T}$ & df & $\begin{array}{c}\text { Sig. } \\
\text { (2-tailed) }\end{array}$ & $\begin{array}{c}\text { Mean } \\
\text { Differenc }\end{array}$ & $\begin{array}{l}\text { Std. Error } \\
\text { Differenc }\end{array}$ & $\begin{array}{r}95 \% \text { Con } \\
\text { of the }\end{array}$ & $\begin{array}{l}\text { Interval } \\
\text { rence }\end{array}$ \\
\hline \multirow{4}{*}{$\begin{array}{l}\text { Global } \\
\text { MRSs }\end{array}$} & & & & & & & & & Lower & Upper \\
\hline & Equal & .031 & .860 & 3.366 & 198 & .001 & -.19960 & .5931 & -.31655 & -.08265 \\
\hline & $\begin{array}{l}\text { variances } \\
\text { assumed }\end{array}$ & & & & & & & & & \\
\hline & $\begin{array}{l}\text { Equal } \\
\text { variances not } \\
\text { assumed }\end{array}$ & & & 3.366 & $1.97983 \mathrm{E} 2$ & .001 & -.19960 & .5931 & -.31656 & -.08264 \\
\hline
\end{tabular}

$\mathrm{P}<0.05$

As displayed in Table $2(\mathrm{t}=3.36, \mathrm{df}=198, \mathrm{P}<0.05)$, the value of $\mathrm{P}$ is 0.001 . Since this figure is lower than 0.05 , it can be concluded that there is a significant difference between monolingual and bilingual learners' awareness and use of Global MRSs.

To investigate the third research question exploring possible significant differences between monolingual and bilingual EFL learners' perceived use of Problem-Solving MRSs, an Independent Samples T-test was run to compare these two groups' mean scores. The results are displayed in Table 3.

Table 3. Independent Samples T-tests for the use of Problem-solving MRSs

\begin{tabular}{rrrrrr}
\hline & Linguality & $\mathrm{N}$ & Mean & Std. Deviation & Std. Error Mean \\
\hline P-S & 100 & 3.12600 & 3.30173 & .33017 \\
& $\begin{array}{c}\text { Monolingual } \\
\text { Bilingual }\end{array}$ & 100 & 3.18000 & 3.56186 & .35619
\end{tabular}

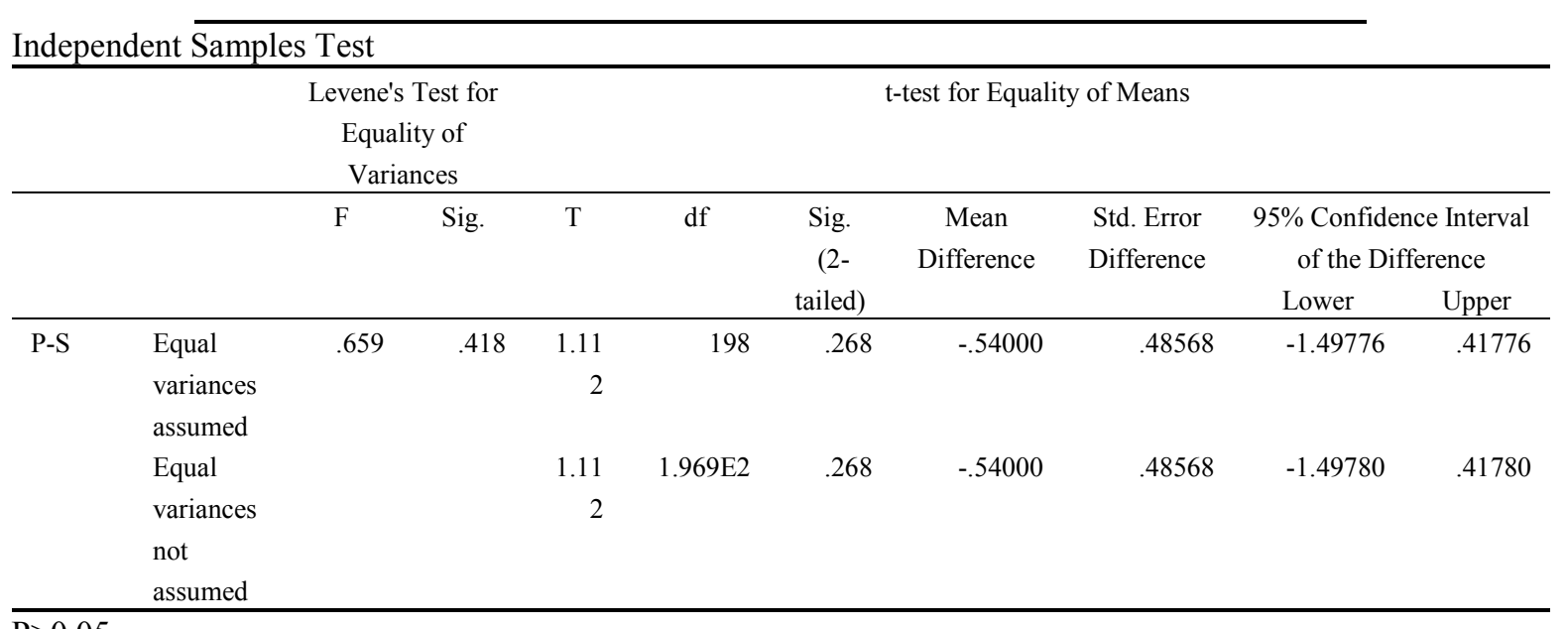


The results of the Independent Samples T-test $(\mathrm{t}=1.11, \mathrm{df}=198, \mathrm{P}<0.05)$ indicate that the value of $\mathrm{P}$ equals 0.26 . Since this figure is greater than the 0.05 level of significance it can be concluded that there is no significant difference between monolingual and bilingual EFL learners' use of Problem Solving MRSs.

To investigate the fourth research question exploring the significant differences between monolingual and bilingual EFL learners' use of Supportive MRSs, an Independent Samples T-test was run to compare the two groups' mean scores, as illustrated in Table 4.

Table 4. Independent sample T-test for Supportive MRSs

\begin{tabular}{llllrr}
\hline & Linguality & $\mathrm{N}$ & \multicolumn{1}{c}{ Mean } & \multicolumn{1}{c}{ Std. Deviation } & \multicolumn{1}{c}{ Std. Error Mean } \\
\hline S- & 100 & 3.3456 & .48715 & .04871 \\
MRSs & $\begin{array}{l}\text { Monolingual } \\
\text { Bilingual }\end{array}$ & 100 & 3.4223 & .52596 & .05260 \\
\hline
\end{tabular}

Independent Samples Test

\begin{tabular}{|c|c|c|c|c|c|c|c|c|c|c|}
\hline & & \multicolumn{2}{|c|}{$\begin{array}{l}\text { Levene's Test } \\
\text { for Equality } \\
\text { of Variances }\end{array}$} & \multicolumn{7}{|c|}{ t-test for Equality of Means } \\
\hline & & \multirow[t]{2}{*}{$\mathrm{F}$} & \multirow[t]{2}{*}{ Sig. } & \multirow[t]{2}{*}{$\mathrm{T}$} & \multirow[t]{2}{*}{$\mathrm{df}$} & \multirow[t]{2}{*}{$\begin{array}{l}\text { Sig. (2- } \\
\text { tailed) }\end{array}$} & \multirow[t]{2}{*}{$\begin{array}{c}\text { Mean } \\
\text { Difference }\end{array}$} & \multirow[t]{2}{*}{$\begin{array}{l}\text { Std. Error } \\
\text { Difference }\end{array}$} & \multicolumn{2}{|c|}{$\begin{array}{l}95 \% \text { Confidence } \\
\text { Interval of the } \\
\text { Difference }\end{array}$} \\
\hline & & & & & & & & & Lower & Upper \\
\hline & $\begin{array}{l}\text { Equal } \\
\text { variances } \\
\text { assumed }\end{array}$ & 1.079 & .300 & $\begin{array}{r}1.07 \\
0\end{array}$ & 198 & .286 & -.07670 & .07169 & -.21807 & .06467 \\
\hline $\begin{array}{l}\text { S- } \\
\text { MRSs }\end{array}$ & $\begin{array}{l}\text { Equal } \\
\text { variances not } \\
\text { assumed }\end{array}$ & & & $\begin{array}{r}1.07 \\
0\end{array}$ & 196.848 & .286 & -.07670 & .07169 & -.21808 & .06468 \\
\hline
\end{tabular}

Key: S-MRSs=Supportive Metacognitive Reading Strategies

As the results show $(\mathrm{t}=1.07, \mathrm{df}=198, \mathrm{P}>0.05)$, the value of $\mathrm{P}$ equals 0.28 , which is greater than the 0.05 level of significance. Thus, it can be concluded that there is no significant difference between monolingual and bilingual EFL learners' use of Supportive MRSs.

To sum up, the results of data analyses revealed that there are significant differences between monolingual and bilingual EFL learners' use of Overall and Global MRSs, but no significant difference was found between monolingual and bilingual EFL learners' use of Problem-solving and Supportive MRSs.

\section{Discussion}

The results of the present study revealed that bilingual EFL learners use overall and global MRSs more than monolingual learners. This finding supports the results of Maghsudi \& Talebi's (2009) study, in which the effect of bilinguality on the awareness and use of cognitive, metacognitive, and total cognitive/metacognitive strategies was investigated with respect to the participants' language proficiency level. The findings of Maghsudi \& Talebi's study indicated that bilingual learners scored significantly higher than their monolingual peers in the awareness and use of the aforementioned strategies.

The findings of the present study are also in line with the results of a research conducted by Hong-Nam \& Leavell (2007), who compared the learning strategy use of 428 Korean monolingual and 420 Korean-Chinese bilingual university students. The bilingual participants in this study used metacognitive strategies most and memory strategies least, while the monolingual learners used compensation strategies most and affective strategies least.

The findings are also in agreement with the results of Tuncer's (2009) research. He investigated the use of language learning strategies by monolingual and bilingual EFL learners, with gender and language proficiency as additional variables. The results of his study indicated that out of these three variables only bilinguality had a significant effect on the use of language learning strategies.

\section{Conclusion and Implications}

The analysis of self-reported data in the present study indicates that bilingual learners use Overall and Global MRSs more than monolingual EFL learners. Based on these results, it can be concluded that bilingualism enhances learners' overall awareness and use of metacognitive reading strategies. In other words, they may "know that information and 
strategies learned or acquired in one language could be used to comprehend texts written in another language" (Garcia et al., 1998, p.204).

With respect to the awareness and use of Supportive and Problem-Solving metacognitive strategies, the present study found that bilingual and monolingual EFL learners were not significantly different in their awareness and perceived use of these two strategies. This may be attributable to variables such as proficiency level and attitudes toward reading that were not taken into consideration in the present research.

Moreover, the findings of the present study revealed that monolingual learners, compared to bilinguals, were less aware of global and overall metacognitive reading strategies. Therefore, EFL teachers should try to increase monolingual students' awareness of such strategies and help them become, what Pressley \& Afflerbach (1995) call, constructively responsive readers.

The main implication of the present study concerns the significant role of metacognitive strategies in the learning process. Teachers need to become familiar with the techniques of learning strategy instruction. They should bear in mind that strategy training is important, and they may need to be trained in how to teach these strategies (O'Malley and Chamot, 1990). Teachers should choose tasks which include reading strategies and they must reflect on how a given strategy can be adequately applied in a particular teaching-learning situation. In other words, they must introduce strategies which can be applied in a variety of reading texts, and students need to be provided with opportunities to practice these strategies.

\section{Suggestions for Further Research}

The bilingual participants in the present study were Azeri-Persian speakers. This study can be replicated with other bilingual students in Iran or elsewhere. Also variables such as language proficiency, gender, and attitudes towards reading that were not investigated in the present study could be taken into consideration in future studies.

\section{Acknowledgement}

The authors wish to thank Dr. Hassan Talebi for his invaluable comments on an earlier version of this paper.

\section{References}

Alexander, P .A., \& Jetton, T. L. (2000). Learning from text: A multidimensional and developmental perspective. In M. L. Kamil, P. Mosenthal, P. D. Pearson, \& R. Barr (eds.), Handbook of reading research (Vol. 3, pp.285-310). Mahwah, NJ: Erlbaum.

Anderson, N. J. (2002). The role of metacognition in second language teaching and learning. ERIC Digest. Available online: http//:www.cal.org/resources/digest/0110anderson.html.

Block, E. (1992). See how they read: Comprehension monitoring of L1 and L2 readers. TESOL Quarterly, 26, $319-343$.

Carrell, P. L. Pharis, B. G., \& Liberto, J. C. (1989). Metacognitive strategy training for ESL reading. TESOL Quarterly, 23, 647-678.

Cenoz, J. \& Valencia, J. F. (1994). Additive trilingualism: Evidence from the Basque country. Applied Psycholinguistics, 15, 195-207.

Cohen, A. D. (1998). Strategies in learning and using a second language. London: Longman.

Garcia, G. E., Jimenez, R. T., \& Pearson, P. D. (1998). Metacognition, childhood bilingualism, and reading. In D. Hacker, J. Dunlowsky, \& A. Graesser (eds.), Metacognition in Educational Theory and Practice (pp. 193-219). New Jersey: Lawrence Erlbaum.

Grabe, W., \& Stoller, F. (2002). Reading for academic purposes: Guidelines for the ESL/EFL teacher. In M. CelceMurcia (ed.), Methods in teaching English as a second or foreign language (pp. 187-204). Boston: Heinle \& Heinle.

Grabe, W., \& Stoller, F. (2002). Teaching and researching reading: Applied linguistics in action. New York: Longman.

Grenfell, M., \& Harris, V. (2006). Strategy use of bilingual learners: A research agenda. Paper presented at the British Educational Research Association Annual Conference, University of Warwick, 6-9 September, 2006.

Guthrie, J., \& Wigfield, A. (1999). How motivation fits into a science of reading. Scientific Studies of Reading, 3, 199205.

Hakuta, K. (1990). Bilingualism \& bilingual education: A research perspective. NCBE FOCUS: Occasional Papers in Bilingual Education, 1, 1-13. Washington, DC: National Clearinghouse for Bilingual Education.

Hardin , V. (2001). Transfer and variation in cognitive reading strategies of Latino fourth-grade students in a late-exit program. Bilingual Research Journal, 25(4), 1-21.

Hong-Nam, K., \& Leavell, A. G. (2007). A comparative study of language learning strategy use in an EFL context: Monolingual Korean and bilingual Korean-Chinese university students. Journal of Asia Pacific Education Review, 8 (1), 71-88. 
Keshavarz, M. H. \& Assar, M. (2009). Reading comprehension ability and metacognitive awareness of reading strategies among high, mid and low ambiguity tolerance EAP students. Iranian Journal of Applied Language Studies, 1 (2), 71-108.

Keshavarz, M. H. \& Astaneh, H. (2004). The impact of bilinguality on the learning of English vocabulary as a foreign language (L3). International Journal of Bilingual Education and Bilingualism, 7 (4), 295-302.

Klein, E. C. (1995). Second versus third language acquisition: Is there a difference? Language Learning, 45 (3), 419 465.

Lawrence, L. J. (2007). Cognitive and metacognitive reading strategies revisited: Implications for instruction. Reading Matrix, 7 (3), 55-71.

Maghsudi, M. \& Talebi, H. (2009). The impact of linguality on the cognitive and metacognitive reading strategies awareness and reading comprehension ability. Journal of Social Sciences, 18 (2), 119-126.

Mokhtari, K., \& Reichard, C. (2002). Assessing students' metacognitive awareness of reading strategies. Journal of Educational Psychology, 94 (2), 249-259.

Moreno, V., \& DiVesta, F. ( 1991). Cross-cultural comparison of study habits. Journal of Educational Psychology, 83 (2), 231-239.

O'Malley, J. M. \& Chamot, A. U. (1990). Learning strategies in second language acquisition. Cambridge: Cambridge University Press.

Oxford, R. L. (1990). Language learning strategies: What every teacher should know. New York: Newbury House.

Padron, Y. N., Knight, S. L., \& Waxman, H. C. (1986). Analyzing bilingual and monolingual students' perception of their reading strategies. The Reading Teacher, 39 (5), 430-433.

Padron,Y. N., \& Waxman, H.(2001). The reading strategies of bilingual and monolingual students. The Journal of Social Psychology, 128 (5), 697-698.

Pressley, M., \& Afflerbach, P. (1995). Verbal protocols of reading: The nature of constructively responsive reading. Hillsdale, NJ: Lawrence Erlbaum Associates Inc.

Pressley, M. (2000). What should comprehension instruction be the instruction of? In M. L. Kamil, P. B. Mosenthal, P. D. Pearson, \& R. Barr (eds.), Handbook of reading research (Vol.3, pp.545-561). Mahwah NJ: Erlbaum.

Santana, J. C. (2003). Moving towards metacognition. Unpublished master's thesis, Universidad Panamericana, Guadalajara. Available online at: www.readingmatrix.com/conference/pp/proceedings2005/Santana.pdf.

Sheory, R. \& Mokhtari, K. (2001). Differences in the metacognitive awareness of reading strategies among native and non-native readers. System, 29, 431-449.

Şenay Şen, H. (2009). The relationship between the use of metacognitive strategies and reading comprehension. Procedia Social and Bilingual Sciences 1, 2301-2305.

Tuncer, U. (2009). How do monolingual and bilingual language learners differ in the use of learning strategies while learning a foreign language? Evidences from Mersin University. Procedia Social and Behavioral Sciences 1, 852-856.

Xianming, X. (2007). A study of first-year college students' metacognitive awareness of reading strategies. Journal of Social Sciences, 1 (1), 93-107.

Zobl, H. (1993). Prior linguistic knowledge and the conservation of the learning procedure: Grammaticality judgments of unilingual and multilingual learners. In S. M. Gass and L. Selinker (eds), Language transfer in language learning (pp. 176-196). Amsterdam: John Benjamins.

\section{Appendix}

Metacognitive Awareness of Reading Strategies Inventory

(MARSI) Version 1.0

Source: Mokhtari, K., and Reichard, C. (2002)

Directions: Listed below are statements about what people do when they read academic or school related materials, such as textbooks, library books, etc. Five numbers follow each statement (1, 2, 3, 4, and 5) and each number means the following:

1 means "I never or almost never do this."

2 means "I do this only occasionally."

3 means "I sometimes do this." (About $50 \%$ of the time.)

4 means "I usually do this."

5 means " I always or almost always do this."

After reading each statement, circle the number $(1,2,3,4,5)$ that applies to you using the scale provided. Please note that there is no right or wrong answers to the statements in this inventory. 


\begin{tabular}{|c|c|c|c|c|c|c|}
\hline TYPE & STRATEGIES & \multicolumn{5}{|c|}{ SCALE } \\
\hline GLOB & $\begin{array}{l}\text { 1. I have a purpose in my mind when I } \\
\text { read. }\end{array}$ & 1 & 2 & 3 & 4 & 5 \\
\hline SUP & 2. I take notes while reading to help me understand what I read. & 1 & 2 & 3 & 4 & 5 \\
\hline GLOB & 3. I think about what I know to help me understand what I read. & 1 & 2 & 3 & 4 & 5 \\
\hline GLOB & 4. I preview the text to see what it's about before reading it. & 1 & 2 & 3 & 4 & 5 \\
\hline SUP & $\begin{array}{l}\text { 5. When a text becomes difficult, I read aloud to help me understand } \\
\text { what I read. }\end{array}$ & 1 & 2 & 3 & 4 & 5 \\
\hline SUP & $\begin{array}{l}\text { 6. I summarize what I read to reflect on important information in the } \\
\text { text. }\end{array}$ & 1 & 2 & 3 & 4 & 5 \\
\hline GLOB & $\begin{array}{l}\text { 7. I think about whether the content of the text fits my reading } \\
\text { purpose. }\end{array}$ & 1 & 2 & 3 & 4 & 5 \\
\hline PROB & $\begin{array}{l}\text { 8. I read slowly but carefully to be sure I understand what I'm } \\
\text { reading. }\end{array}$ & 1 & 2 & 3 & 4 & 5 \\
\hline SUP & 9. I discuss what I read with others to check my understanding. & 1 & 2 & 3 & 4 & 5 \\
\hline GLOB & $\begin{array}{l}\text { 10. I skim the text first by noting characteristics like length and } \\
\text { organization. }\end{array}$ & 1 & 2 & 3 & 4 & 5 \\
\hline PROB & 11. I try to get back on track when I lose concentration. & 1 & 2 & 3 & 4 & 5 \\
\hline SUP & $\begin{array}{l}\text { 12. I underline or circle information in the text to help me remember } \\
\text { it. }\end{array}$ & 1 & 2 & 3 & 4 & 5 \\
\hline PROB & 13. I adjust my reading speed according to what I'm reading. & 1 & 2 & 3 & 4 & 5 \\
\hline GLOB & 14. I decide what to read closely and what to ignore. & 1 & 2 & 3 & 4 & 5 \\
\hline SUP & $\begin{array}{l}\text { 15. I use reference materials such as dictionaries to help me } \\
\text { understand what I read. }\end{array}$ & 1 & 2 & 3 & 4 & 5 \\
\hline PROB & $\begin{array}{l}\text { 16. When text becomes difficult, I pay closer attention to what I'm } \\
\text { reading. }\end{array}$ & 1 & 2 & 3 & 4 & 5 \\
\hline GLOB & $\begin{array}{l}\text { 17. I use tables, figures, and pictures in text to increase my } \\
\text { understanding. }\end{array}$ & 1 & 2 & 3 & 4 & 5 \\
\hline PROB & 18. I stop from time to time and think about what I'm reading. & 1 & 2 & 3 & 4 & 5 \\
\hline GLOB & 19. I use context clues to help me better understand what I'm reading. & 1 & 2 & 3 & 4 & 5 \\
\hline SUP & $\begin{array}{l}\text { 20. I paraphrase (restate ideas in my own words) to better understand } \\
\text { what I read. }\end{array}$ & 1 & 2 & 3 & 4 & 5 \\
\hline PROB & $\begin{array}{l}21 . \text { I try to picture or visualize information to help remember what I } \\
\text { read. }\end{array}$ & 1 & 2 & 3 & 4 & 5 \\
\hline GLOB & $\begin{array}{l}\text { 22. I use typographical aids like bold face and italics to identify key } \\
\text { information. }\end{array}$ & 1 & 2 & 3 & 4 & 5 \\
\hline GLOB & $\begin{array}{l}\text { 23. I critically analyze and evaluate the information presented in the } \\
\text { text. }\end{array}$ & 1 & 2 & 3 & 4 & 5 \\
\hline SUP & $\begin{array}{l}\text { 24. I go back and forth in the text to find relationships among ideas } \\
\text { in it. }\end{array}$ & 1 & 2 & 3 & 4 & 5 \\
\hline GLOB & $\begin{array}{l}\text { 25. I check my understanding when I come across conflicting } \\
\text { information. }\end{array}$ & 1 & 2 & 3 & 4 & 5 \\
\hline GLOB & 26. I try to guess what the material is about when I read. & 1 & 2 & 3 & 4 & 5 \\
\hline PROB & $\begin{array}{l}\text { 27. When text becomes difficult, I re-read to increase my } \\
\text { understanding. }\end{array}$ & 1 & 2 & 3 & 4 & 5 \\
\hline SUP & 28. I ask myself questions I like to have answered in the text. & 1 & 2 & 3 & 4 & 5 \\
\hline GLOB & 29. I check to see if my guesses about the text are right or wrong. & 1 & 2 & 3 & 4 & 5 \\
\hline PROB & 30. I try to guess the meaning of unknown words or phrases. & 1 & 2 & 3 & 4 & 5 \\
\hline
\end{tabular}

Source: Mokhtari, K. \& Reichard, C. (2002). Assessing students' metacognitive awareness of reading strategies .Journal of Educational Psychology, 94(2), 249-259. 